\title{
ENVIRONMENTALLY FRIENDLY AND ECONOMICALLY SUSTAINABLE LOCAL PEATLAND CULTIVATION STRATEGIES
}

\author{
${ }^{1}$ Muhammad Noor Fazri Edison, ${ }^{2}$ Suprayitno, ${ }^{3}$ Niwayan Sukraini, \\ ${ }^{1}$ Universitas Muhammadiyah Palangka Raya, Palangka Raya, Indonesia \\ ${ }^{2}$ Universitas Palangka Raya, Palangka Raya, Indonesia \\ ${ }^{3}$ Institut Agama Hindu Negeri Palangka Raya, Palangka Raya, Indonesia \\ Iffazriedison@gmail.com, ${ }^{2}$ suprayitno@fisip.upr.ac.id, ${ }^{3}$ niwayansukraini@gmail.com
}

\begin{abstract}
Kalampangan subdistrict is located in the north part of Palangka Raya Town in Central Kalimantan. Kalampangan was built on approximately four-meter-deep peat. At first, the land was not productive because it was very acidic. However, after many years of hard work, Kalampangan has been successful in providing vegetables, fruits, and meat for Palangka Raya and its surrounding regions. The local farmers in Kalampangan cultivate the deep peatland in an environmentally friendly way, i.e., by adding manure and ash of weeds. As a result of this local wisdom-based practice, the soil becomes fertile and productive for horticultural products, and subsequently, the plant residue is utilized for animal feed. This integrated horticulture and livestock farming have made Kalampangan the biggest produce and livestock supplier for Palangka Raya and the surrounding regions. This paper aims at describing the detailed strategies of this integration by collecting data through interviews with the local administration and farmers.
\end{abstract}

Keywords: Kalampangan, peatland, horticulture, livestock farming, productive

DOI: $10.33541 /$ sp.v21i3.2247

Sociae Polites : Majalah Ilmiah Sosial Politik

Faculty of Social and Political Science, Universitas Kristen Indonesia

ISSN 1410-3745 print/ ISSN 2620-4975 online

Volume 21, Number 2 (Youth Peatland Conference)

Pages 171-178 


\section{Introduction}

It is intriguing to know how Kalampangan, a subdistrict with a population of 3.910 located on deep peat, becomes the biggest supplier of horticultural products and meat for approximately more than 244.500 people of Palangka Raya.

\subsection{Background}

Kalampangan subdistrict is situated $18 \mathrm{~km}$ north of Palangka Raya Town in Central Kalimantan. Kalampangan was built on approximately four-meter-deep peat. At first, the land was not productive because it was very acidic. However, after many years of hard work, Kalampangan has been successful in providing vegetables and meat for Palangka Raya and its surrounding regions.

Central Kalimantan used to have a tendency to employ shifting cultivation to grow crops and vegetables. The farmers in Kalampangan do not do shifting cultivation, let alone clearing a new land by burning. Instead, the farmers choose to cultivate the peat in environmentally sustainable ways. Furthermore, this practice results in a strong integration of horticulture and livestock farming.

It is necessary to further study the strategies used by the farmers and the internal and external factors of Kalampangan Subdistrict. The results of the study will be able to be implemented in other regions of Central Kalimantan.

\subsection{Research Questions}

Based on a description in the background, the research questions which the writers attempt to answer are as follows.

a. What are the strategies used by farmers to cultivate the peatland to become productive for horticulture?

b. How do the farmers integrate horticulture and livestock farming on peatland?

\subsection{Purpose and objective}

The following are the objectives of this study.

a. to describe the strategies used by farmers to cultivate the peatland to become productive for horticulture

b. to describe how the farmers integrate horticulture and livestock farming on peatland

\section{Literature Review}

\subsection{Strategies to Integrate Horticulture and Livestock Farming in Peatland}

The strategy is a plan used to integrate goals, wisdom, and actions to become a union (Quinn, 1999:10). Some other literature defines strategy in more detail. David (2011:18-19) interprets strategy as a means with long-term goals as a target of achievement. According to Pierce II and Robinson (2008:2), the strategy includes a big plan with a future orientation to interact with competing situations to achieve a goal. While Daft (2002) in Suprayitno et al. (2019: 250) explains that strategy is an action plan that details resources and activities in response to the environment and to help achieve goals and targets. In conclusion, strategy means a planned attempt to reach future goals. 
Regarding the word integration, Puspito (1989) defines it as a continuity of different aspects to become harmonious unity. According to Widjaja (1986), integration means harmony of units in a system, and they do not harm each other. Another perspective comes from Sugiarto and Fajarhati (2008), who explain integration is required in organizations in which departments need data from one another.

Because this paper focuses on the integration of horticulture and livestock farming in the Kalampangan subdistrict, we find it necessary to seek an explanation about agriculture as it branches out to horticulture. Sumantri (1980) defines agriculture as all biophysical aspects related to the improvement of plant cultivation to obtain maximum physical production. Funneling to one of the branches, Zulkarnain (2009) explains that horticulture relates to intensive food cultivation, which caters to human food consumption, medicinal purposes, and satisfaction because horticulture includes cultivation for vegetables, fruits, and ornamental plants. Horticulture has a huge role in providing nutritious food for society, creating job opportunities, and supporting agro-tourism and agro-industry activities.

As for the phrase livestock farming, According to Undang-Undang RI Nomor 18 Tahun 2009 on Livestock and Animal Health, livestock farming means any matter that involves physical resources, seeds, seedlings, feed, farming tools and machinery, livestock farming, harvesting, post-harvest, processing, marketing, and cultivation. Reksohadiprodjo (1995) defines livestock farming as an attempt to gain benefits from livestock cultivation for human consumption. Therefore, livestock farming is "simply the management and breeding of domestic, livestock or farm animals for the purpose of obtaining their meat and products." (Akinbabola, 2020).

Since Kalampangan Subdistrict is located on peatland, it is necessary to learn what peat is and its characteristics. It is generally known that peat is a type of soil that is formed from decayed vegetation. Agus and Subiksa (2008) describe peatland as a piece of land whose soil consists of organic matter containing carbon (around 18\%) with a thickness of more than 50 centimeters. It takes a very long time, around ten years, to form one centimeter of peat (Dion dan Nautiyal, 2008). Furthermore, peat has relatively high acidity, i.e., 3-4 pH (Hartatik et al.).

\subsection{Previous Studies}

Lingga et al. (2018), in their study on strategies for developing vegetable growing in Kalampangan Subdistrict, do a S.W.O.T analysis of this practice. The strength of the cultivation is the ample land for use, and the weakness is not very fertile soil. While there is a big opportunity in this venture, i.e., increasing demand for vegetables, there is also a threat from other regions such as competition.

The strategies formulated based on this study are as follows. (1) to optimize the land potential by opening road access to a growing field, (2) to expand the growing area, (3) to learn technology development in organic vegetable growing, (4) expand the business by utilizing capital assistance, (5) to increase production and harvest quality, (6) to cultivate peatland for growing, and (7) to minimize cost.

Another similar research was conducted by Firmansyah (2016), where he attempted to generate strategies for organic vegetable growing in Bangkit Merbabu, Semarang, Central Java. The internal factors of organic vegetable growing in this region include not using pesticides as the strength and not having a good management system as the weakness. Furthermore, the external factors are a huge market in the country and abroad as the opportunity and easy access to product substitute as the threat.

The following are the strategies formulated by Firmansyah (2016). (1) to continuously maintain and increase the quality of organic vegetable, (2) to monitor the cultivation process 
until post-harvest, (3) to increase production to meet market demand, (4) expand the growing area and maintain coordination among the members of sub assisted groups, (5) increase coordination with government and private sectors in getting capital assistance and training, (6) in increasing growers' knowledge and competence in organic vegetable cultivation, (7) maintain and improve coordination with partners, and (8) to learn technology development in organic vegetable cultivation.

Regarding plants and livestock farming integration, Kariyasa (2005) focuses on the use of fertilizer for growing horticultural plants. He explains that continuous and extensive use of inorganic fertilizer has led growing fields in Indonesia to a miserable condition. Besides, the government-subsidized inorganic fertilizer is not effective, proven by increasing price and scarcity of fertilizer at the beginning of the planting period. He then concludes that the use of organic fertilizer, such as manure from livestock farming, is proven to increase growers' productivity and profit, as well as reduce the cost.

\section{Research Methods}

\subsection{Setting}

This study was conducted in the Kalampangan Subdistrict, part of the Town of Palangka Raya in Central Kalimantan Province. It took approximately one month to complete this study, which includes activities such as preparation, research development, data synchronization, and result details.

\subsection{Method}

Sugiono (2010) shows that the qualitative research method refers to a method used to study a scientific object in which the researcher is the main instrument. As a research instrument, the researcher has to possess a strong understanding of theories in order to qualify in asking questions, analyzing, capturing, and constructing social situations to make them clear and meaningful. As affirmed by Setiawan and Saryono (2010), the objective of the qualitative research method is to investigate, find, describe, and explain the quality of social influence, which cannot be described, explained, or measured using quantitative research method. Therefore, because this study aims at describing the strategies to integrate horticulture and livestock farming, the research method used is qualitative.

\subsection{Data Collection}

Two types of data were used in this study, i.e., primary data and secondary data. The primary data was obtained through direct field observation and interviews with vegetable growers, livestock farmers, and an agro-tourism spot owner in Kalampangan Subdistrict. The guided interviews were based on several questions prepared beforehand, which included asking information regarding the interviewers' personal information, the techniques of their land cultivation, the integration of horticulture and livestock farming, and some other variables.

The secondary data was collected through document review obtained from the administration office of Kalampangan Subdistrict and local government office of food crops, horticulture, and animal husbandry. The data from these offices include administrative matters such as land area, population, etc.

\subsection{Data Analysis}


After being collected, the data was then analyzed by identifying relevant information obtained from the informants, looking for the similarities and the differences, and finding significant patterns.

\section{Results and Discussions}

The following describes the findings from the direct field observation and the in-depth interviews with four informants ST, YR, SN, and R.O.

\subsection{The method used to cultivate peatland}

All informants agreed that in Kalampangan, the growers did not burn the peatland when converting to the horticulture cultivation field. Only occasionally did they burn dried weeds after pulling them to add to the soil as fertilizer. The growers dug out the peat and added manure.

4.2. Types of horticultural plants that can be grown in environmentally friendly ways

S.T. mentioned most types of vegetables, fruits, and tubers they grew in Kalampangan Subdistrict. Among them are mustard greens, spinach, water spinach, tomato, eggplant, celery, spring onion, lettuce, corn, pineapple, watermelon, dragon fruit, melon, potato, taro, and cassava. S.T. added that if there were unintentionally grown plants such as banana, the growers just let it grow. Y.R. affirmed S.T.'s statements, and he added that most growers try to cultivate different plants to promote more variety and reduce competition. Y.R. personally only grew corn, celery, and spring onion, while S.N. even limits his crops to only celery and spring onion.

\subsection{Integration with livestock farming}

The informants said that generally, farmers in Kalampangan only farm chicken, cattle, and goats. Some area of the land is dedicated to growing grass for the animals. Besides, the farmers also utilize the residue of horticulture plants for animal feed. As for the plants, the farmers use animal waste, which becomes manure, to fertilize the soil. It is a mutual symbiosis.

\subsection{Utilizing peatland for agro-tourism}

Kalampangan Subdistrict has evolved its potential to agro-tourism. D.R. mentioned that, with support from the Palangka Raya administration, Kalampang had developed fruit orchards as agro-tourism spots, such as dragon fruit orchard and seedless guava orchard. Some farmers also open their vegetable cultivations for tourists. R.O. informed the interviewer that when cultivating the land for fruit orchards, the growers did not burn the peat. Instead, they dug it out with an excavator, and they fertilize the soil with manure.

\section{Conclusions and recommendations}

\subsection{Conclusions}


Based on the research findings, it can be concluded that in cultivating their land, the farmers in Kalampangan Subdistrict use environmentally friendly ways. They did not burn the peat. They fertilized the soil with manure and the ash of weeds as fertilizers. The horticultural products grown in Kalampangan Subdistrict include vegetables, fruits, and tubers. The animals raised in the farms are cattle, chickens, and goats. Moreover, the integration of horticulture and livestock farming is in utilizing plant residue as animal feed and in using manure from the animal dung as fertilizer.

\subsection{Recommendations}

The researchers recommend the following points.

a. Palangka Raya administration should expand productive land in other parts of the municipality so that they can be as successful as Kalampangan Subdistrict.

b. The farmers in Kalampangan should be continuously assisted by the local government in order to increase productivity.

c. It is necessary to extend the market to other regencies in Central Kalimantan to prevent decreased prices post big harvest. 


\section{BIBLIOGRAPHY}

\section{Book}

Agus, F. and Subiksa, I.G.M. 2008. Lahan Gambut: Potensi untuk Pertanian dan Aspek Lingkungan. Balai Penelitian Tanah Dan World Agroforestry Centre (ICRAF). Bogor.

Cameron, K.S., and Quinn, R.E. 2011. Diagnosing and Changing Organizational Culture. 3rd ed., Jossey Bass Wiley.

Daft, R.L. 2002. Manajemen Edisi Kelima Jilid Satu. Jakarta : Erlangga.

David, F.R. 2011. Manajemen Strategis, Buku 1, Edisi 12, Jakarta: Penerbit Salemba Empat.

Dion, P. dan Nautiyal, C.S. (eds). 2008. Microbiology of Extreme Soils. Soil. Biology 13. Berlin: Springer-Verlag.

Pearce II, J. and Robinson, R. 2008. Manajemen Strategis Formulasi, Implementasi dan Pengendalian. Jakarta: Salemba Empat.

Puspito, H. 1989. Sosiologi Sistematik. Yogyakarta: Kanisius.

Reksohadiprodjo, S. 1995. Manajemen Produksi dan Operasi. Edisi Pertama. Yogyakarta: BPFE-Yogyakarta.

Setiawan, A. dan Saryono. 2010. Metodologi Penelitian kebidanan. Jakarta: Nuha Medika.

Sugiarto, M. dan Fajarhati, P. 2008. Implementasi Integrasi Data Antar Sistem Informasi Untuk Mendukung Decission Support System. Konferensi dan Temu Nasional Teknologi Informasi dan Komunikasi untuk Indonesia.

Sugiono. 2006. Metode Penelitian Kualitatif dan R\&D. Bandung: Alfabeta.

Sumantri.1980. Pengantar Agronomi. Jakarta: PT. Gramedia.

Widjaja, A.W. (1986). Individu, Keluarga dan Masyarakat. Jakarta: Akademika Persindo

Zulkarnain. (2009). Dasar-dasar Hortikultura. Jakarta: Bumi Aksara.

\section{Journal}

Kariyasa, K. 2005. "Sistem Integrasi Tanaman-Ternak dalam Perspektif Reorientasi Kebijakan Subsidi Pupuk dan Peningkatan Pendapatan Petani.” Analisis Kebijakan Pertanian. 3:68-80.

Lingga, R.M., Mukti, A., and Wardie, J. 2018. "Strategi Pengembangan Usaha tani Sayuran di Kelurahan Kalampangan Kecamatan Sabangau kota Palangka Raya." Journal Socio Economics Agricultural. 13:64-78.

Suprayitno, S., Riamona, S.T., Ira, Z. (2018). The Strategy to Increase the Regional Revenue (P.A.D.) of the Government of Central Kalimantan through the Governor Regulation No. 16/2018. Policy \& Governance Review. 2(3). 245-260.

\section{Thesis}

Firmansyah, B.Y. 2016. "Strategi Pengembangan Usahatani Sayuran Organik Kelompok Tani Bangkit Merbabu di Kabupaten Semarang Provinsi Jawa Tengah." Thesis. Universitas Kristen Satya Wacana.

\section{Website}


Akinbabola, A. 2020. "Livestock Farming: Definition, Benefits and Types.” Accessed on 27 October 2020. https://www.livestocking.net/livestock-farmingoverview\#: :text=Livestock\%20farming\%20is\%20simply\%20the, $\% 2 \mathrm{C} \% 20$ leather $\% 2 \mathrm{C}$ $\% 20$ etc.).

Hartatik, W., Subiksa, dan Dariah, A. Sifat Kimia dan Fisik Tanah Gambut. Accessed on 27 October 2020.

http://balittanah.litbang.pertanian.go.id/ind/dokumentasi/lainnya/wiwik\%20hartatik.pdf 